\title{
Using electronic sensors to support gender neutral STEM activities in primary school
}

\author{
Maria Jão Silva \\ Escola Superior de Educação de \\ Lisboa \\ Instituto Politécnico de Lisboa \\ Lisboa, Portugal \\ mjsilva@eselx.ipl.pt
}

\author{
Eduarda Ferreira \\ Interdisciplinary Centre of Social \\ Sciences (CICS.NOVA), FCSH/NOVA \\ Lisboa, Portugal \\ e.ferreira@fcsh.unl.pt
}

\author{
Susana Batista \\ Interdisciplinary Centre of Social \\ Sciences (CICS.NOVA), FCSH/NOVA \\ Lisboa, Portugal \\ susanabatista@fcsh.unl.pt
}

\begin{abstract}
The Science, Technology, Engineering, and Mathematics (STEM) gender divide is still a nowadays multidimensional problem. During the last decades, research has been studying the factors that can contribute to close the gender gap in what concerns participation, achievement and progression in STEM education. The empirical study presented in this paper assessed, with a gender perspective, the results of the use of electronic sensors to explore and solve environmental health problems by children of four primary school classes. The developed experiment was designed to promote gender inclusion. The results evidenced that children acquired knowledge linked to the use of the sensors, and were able to produce suggestions to solve the explored problems. Nonetheless, gender differences were not promoted by the experiment didactic activities, evidencing affordances of such activities to narrow gender gaps.
\end{abstract}

Keywords - electronic sensors, gender, children, environmental health

\section{INTRODUCTION}

The STEM, and the Information and Communication Technologies (ICT), gender divide/gaps are still nowadays problems that prevent the full participation in the economic, social and cultural life [1], delay scientific excellence and are an obstacle to the quality of STEM outcomes, this way negatively impacting development [2] [3]. Girls appear to lose interest in STEM subjects, and in ICT, with age, and early interventions are needed to sustain girls' interest in these fields [3] [4].

The research presented in this paper intends to assess, with a gender perspective, the results of an experiment that integrated the use, by children of four primary school classes, of electronic sensors, together with tablets, to explore and solve environmental health problems. That experiment was part of the Eco-Sensors4Health Project.

In this research, the use, by primary school children, of electronic sensors, and tablets, in environmental health activities, was designed to engage girls, as well as boys, overcoming gender stereotypes, since:

- The activities took place in formal education contexts, in primary schools where activities are meant for all (boys and girls);

- $\quad$ The used electronic sensors are not gender marked as other technologic tools/toys, with catalogues, guides and papers, showing photos of boys and girls using them [5] [6] [7].

- Tablets have been shown to have affordances to be used by children [8]. In Portugal, tablets are more owned and used by girls than by boys [9], and allow collaborative work that seems to also engage girls [3] [10].

This paper opens with the present introduction, follows with a theoretical framework, and the presentation of the methods employed. Furthermore, the results are then displayed and analyzed. Finally, the conclusions are exposed.

\section{THEORETICAL FRAMEWORK}

\section{A. The STEM and ICT, gender gaps}

Gender differences in STEM have been reported in most countries, with girls and women being underrepresented and less engaged, specially in fields that focus on inorganic phenomena (e.g., computer science), although well represented in the social and life sciences [11]. ICT is one STEM career path, and it is progressively more used as a working tool in STEM education [3].

While gender differences in science and mathematics achievement appear to have decreased in recent years in many countries, as shown in large-scale cross-national surveys, they have not been eliminated [12]. TIMSS (Trends in International Mathematics and Science Studies) is an international study developed by the International Association for the Evaluation of Educational Achievement and assesses mathematics and science literacy in $4^{\text {th }}$ grade students [13]. In TIMMS 1995, gender differences in mathematics were small, but there was a gender gap in science with boys having better results than girls in about half the countries [13]. In TIMMS 2015, twenty years later, the gender gap in mathematics increased, but the gender gap in science decreased, with boys outperforming girls in only five countries (about one-seventh), and girls outperforming boys in 14 countries (more than onethird), with a considerable average achievement difference [13].

In Portugal, the TIMMS 2015 results in science and mathematics were higher for boys, with a higher difference in math, with both differences being statistically significant [14].

Globally, the digital skills gender gap is widening, rather than narrowing, and surpassing the gender gap in digital access. In a world with more access to digital technologies, women are less likely than men to know how to leverage ICT for basic purposes, and this gap grows wider along the skills spectrum [3]. At the same time, the STEM gender gap is "especially large in authorship positions associated with seniority, and prestigious journals have fewer women authors" [15].

The Eco-Sensors4Health project (LISBOA-01-0145-FEDER-023235) is supported by FEDER (PORTUGAL2020) and Portugal State Budget (FCT). 
To close the STEM gender gap is as important as scientific literacy and technological literacy are foundational literacies of the 21st-century skills [12]. On the other hand, science, technology and innovation are also fundamental to the Sustainable Development Goals, since they have a key role in addressing environmental and human problems, such as limited healthcare, climate change, and declining of biodiversity [3].

Furthermore, as digitalization accelerates, digital skills are essential for full participation in society, and contribute to women's and men's, citizenship, to reduce the gender wage gap, and to increase profits, productivity and innovation for technology companies [3].

\section{B. Strategies to overcome the STEM, and ICT, gender gaps}

The analysis of the literature suggests that the differential achievement in science and mathematics is strongly influenced by sociocultural stereotypes that define boys as more capable than girls to the scientific and technological areas. Differences in the learning styles and mental processes used by each sex seem to have less importance in the academic results [10].

Two central stereotypes - 'boys are better at maths and science than girls' and 'science and engineering careers are masculine domains' - decrease girls' interest, which is linked to self-efficacy, engagement and achievement in STEM and discourage them from following STEM careers [3].

Research produced several suggestions to make STEM curricula more attractive to girls [3]:

- Not only male, but also female teachers;

- No classroom hierarchies favoring boys;

- $\quad$ Female role models;

- Learning resources free of gender stereotypes;

- Gender neutral language;

- $\quad$ Relevance to real world;

- Opportunities for hands-on activities, project-based learning, and inquiry, with experimentation, practice, real-world experience, reflection and conceptualization;

- More time and experience with technology

All these suggestions are also key factors to overcome the digital skills gender gap, with an emphasis on embedding digital technologies in collaborative primary education activities, before the girls' decline of interest in ICT observed by research [4].

Furthermore, hands-on activities and inquiry are also important to the engagement of all students, boys and girls [16]: "Evidence suggests that this is best achieved through opportunities for extended investigative work and 'hands-on' experimentation and not through a stress on the acquisition of canonical concepts" [16].

\section{Co-construction of gender, science and ICT}

Gender, science and ICT are social constructions that are co-constructed [17] [18] [19], and to address the ways in which gender makes a difference in this construction is fundamental to close the STEM and ICT gender gaps.
The approach adopted in this research is based on the assumption that there is no need to ghettoizing girls as a population that needs 'special help' in their relation to science and technology, and that it is possible to create activities for all children, in which boys and girls express aspects of selfidentity that transcend stereotyped gender categories [20].

\section{METHODS}

The didactic experiment that is assessed in this study was developed in the context of the Eco-Sensors4Health Project (Eco-sensors for health: Supporting children to create ecohealthy schools), in four classes of the $4^{\text {th }}$ grade, in four different primary schools in Lisbon. That intervention used a scientific inquiry approach that made use of electronic sensors to support children, in a gender inclusive way, in solving sound pollution problems of each school. A questionnaire was applied before (pretest) and after (posttest) the intervention.

Two research questions were defined to the assessment of the aforementioned didactic experiment:

- Were there gender differences in the children's answers to posttest?

- Were there gender differences in the suggestions to solve the school sound problems?

\section{A. Characteristics of the didactic experiment}

The participants of the didactic experiment in each of the four schools were the teacher and the children of each class, and the female research grant holder of the EcoSensors4Health Project. Seventy-two children participated, forty-three girls and twenty-nine boys (Table I).

TABLE I. NUMBER OF GIRLS AND BOYS PER SCHOOL

\begin{tabular}{|l|c|c|c|c|c|}
\hline & School 1 & School 2 & School 3 & School 4 & Total \\
\hline Girls & 12 & 14 & 8 & 9 & 43 \\
\hline Boys & 5 & 7 & 6 & 11 & 29 \\
\hline
\end{tabular}

At school 3 some children did not participate in all the sessions of the didactic experiment, and as such only the responses of 14 children were considered.

The experiment was structured in four sessions of 90 minutes each. In Session 1, the activities were centered on the questions: i) What is sound? ii) What is needed to have sound? iii) How can we observe the sound waves? iv) How does sound come to our eardrums? v) What happens if the eardrum is damaged? vi) How can we protect our eardrums?

To answer those questions, children performed the following tasks: i) Put their hands on their throats as they speak and describe the sensation; ii) Observe the behavior difference of the sugar grains on tightly stretched and poorly stretched adherent film on the top of a drum, when producing sound with a stick on a pan lid. Interpret the results; iii) Feel the vibration of a tuning fork by holding the instrument at its base, while listening to the sound; iv) Watch a video on irreparable hearing damage.

In Session 2, the activities were centered on the questions: i) Do sound waves propagate in the same way in solids and gases? ii) How does sound level vary, when we change our location in school? 
To answer the first question, each child used a pencil and a metal hanger to hear the sound of the pencil hitting the hanger with the hanger against his/er ear, and with the hanger a few centimeters distant from his/er ear. Children identified which of the sounds were stronger, and interpreted the results. An embodied simulation of the propagation of sound waves was also performed, with children in line playing the role of particles in a gas and in a solid. The first child in line was pushed to hit the second child, the second hit the third, and so on... When simulating a solid, children were closer to each other, the propagation was faster and the hits were stronger, comparing to when children were simulating a gas, and were farther from each other. To answer the second question, children used the sound level sensors (PASPORT Sound Level Sensor - PS-2109), together with the tablets, to measure the sound level at the canteen at lunch, and at the corridor, during the class break. Children registered the acquired data in the registration forms.

In session 3, the activities were centered on three questions: i) How does sound level change, when we perform different activities in the classroom? ii) How does sound level change, when we change our location at school? iii) How can we lower sound level, when there is a sound source?

In order to answer to the first two questions, children used sound level sensors to acquire, in groups, sound level data while making silence, clapping hands, and singing, first in the classroom and then outdoors. They register, in the registration form, the minimum sound level, while making silence, the maximum sound level, while clapping hands, and the average, while singing. Afterwards, using a sound scale, they classified the registered values as safe or unsafe to hearing health.

To answer the third question, children measure the sound level of an alarm clock, first out and then inside an empty box and, afterwards inside the same box but wrapped in crumpled paper. With teacher mediation, they registered and interpreted the sound level in the three situations.

Session 4 was the concluding session. In this session, children introduced and visualized the acquired sound level data, in the Eco-Sensors4Health Platform (http://www.ecosensors4health.pt/). They also answered two questions: i) How can we protect our hearing health at school? ii) How can we reduce sound levels in our school? In this way, children made suggestions to solve environmental health problems in their school. Finally, children answered to the posttest questionnaire.

\section{B. Methods and techniques for data collection and processing}

In order to answer to the research questions, "Were there gender differences in the children's answers to the posttest?", "Were there gender differences in the suggestions to solve the school sound problems?", the grant holder of the EcoSensors4Health Project collected the children's answers to the pre and posttests, and to the questions that asked for suggestions to solve sound pollution problems.

The pre and posttest included questions in the following categories: Knowledge, Environmental and Health Awareness, Attitudes, Personal Investment and Responsibility, Perception of the Physical Environment (Table II).
TABLE II. QUESTIONS OF THE PRE AND POSTEST

\begin{tabular}{|c|c|}
\hline Categories & Questions \\
\hline Knowledge & $\begin{array}{l}\text { - To improve the quality of the environment, } \\
\text { noise should be avoided } \\
\text { - A high sound level is harmful to health } \\
\text { - There are always sounds in the classroom, } \\
\text { even when we are silent } \\
\text { - Airing the room is important for health } \\
\text { - Our breathing can pollute the room air }\end{array}$ \\
\hline $\begin{array}{l}\text { Environmental and } \\
\text { Health Awareness }\end{array}$ & $\begin{array}{l}\text { - I pay close attention to health news } \\
\text { - I pay close attention to the news about the } \\
\text { environment }\end{array}$ \\
\hline Attitudes & $\begin{array}{l}\text { - People should think about the importance of } \\
\text { the environment } \\
\text { - I think very little about the environment } \\
\text { - I think very little about health }\end{array}$ \\
\hline $\begin{array}{r}\text { Personal } \\
\text { Investment and } \\
\text { Responsibility }\end{array}$ & $\begin{array}{l}\text { - My health depends a lot on my behavior } \\
\text { - Only experts can reduce the pollution of an } \\
\text { environment } \\
\text { - I can do something to solve the environmental } \\
\text { problems of my school } \\
\text { - We can help colleagues from other classes to } \\
\text { take better care of the environment } \\
\text { - We can help colleagues from other classes to } \\
\text { take better care of their health } \\
\text { - I can change the temperature of my classroom }\end{array}$ \\
\hline $\begin{array}{r}\text { Perception of the } \\
\text { Physical } \\
\text { Environment }\end{array}$ & $\begin{array}{l}\text { - There are environmental problems at my } \\
\text { school. } \\
\text { - An uncomfortable temperature makes it } \\
\text { difficult to be with attention in class }\end{array}$ \\
\hline
\end{tabular}

The pre and posttest were used in other experiments related with thermal (dis)confort and air pollution (concentration of carbon dioxide), which is the reason why some of the knowledge questions are focused on that subjects. However, only the knowledge questions related to the sound pollution were analyzed in this assessment.

Children were asked to position themselves in a concordance scale of 5 levels, identified with the following statements and symbols: Totally disagree ( Disagree ( Neither agree nor disagree (no symbol), Agree (). Totally agree ( Their quantitative correspondence ranged from 1 (Totally disagree) to 5 (Totally agree).

All the answers of the seventy-two participating children were analyzed in detail before analyzing the differences between girls and boys. The nonparametric Wilcoxon test was used to determine if the answers of children to the questions of the pretest and of the posttest are different in a statistically significant way.

The nonparametric Mann-Whitney test was used to determine if the answers of boys and girls to the questions of the posttest are different in a statistically significant way.

\section{RESULTS}

The analysis of the results was based on the answers to the pre and posttest questions and children's suggestions to solve the school sound problems and to protect sound hearing. Nevertheless, it is important to previously stress that all children were able to acquire, register, and interpret sound data that were central to explore and solve the school sound pollution problem. 


\section{A. Pre and posttest analysis}

In the questions of the knowledge category related to the sound experiment there were significant differences between the pre and the posttest answers (Table III).

TABLE III. DIFFERENCES BETWEEN THE PRE AND THE POSTTEST ANSWERS TO THE KNOWLEDGE QUESTIONS ABOUT SOUND

\begin{tabular}{|c|c|c|c|}
\hline Questions & $\begin{array}{l}\text { Pretest } \\
\text { average } \\
\text { and } \\
\text { standard } \\
\text { deviation }\end{array}$ & $\begin{array}{l}\text { Posttest } \\
\text { average } \\
\text { and } \\
\text { standard } \\
\text { deviation }\end{array}$ & $\begin{array}{l}\text { Wilcoxon } \\
\text { test }\end{array}$ \\
\hline $\begin{array}{r}\text { To improve the quality } \\
\text { of the environment, } \\
\text { noise should be } \\
\text { avoided }\end{array}$ & $\begin{array}{c}3,88 \\
(1,10)\end{array}$ & $\begin{array}{c}4,29 \\
(0,91)\end{array}$ & $\begin{array}{c}\mathrm{W}= \\
-2,408 \mathrm{p}<.05\end{array}$ \\
\hline $\begin{array}{l}\text { A high sound level is } \\
\text { harmful to health }\end{array}$ & $\begin{array}{c}3,64 \\
(1,01)\end{array}$ & $\begin{array}{c}4,07 \\
(1,24)\end{array}$ & $\begin{array}{c}W= \\
-2,504 p<.05\end{array}$ \\
\hline $\begin{array}{r}\text { There are always } \\
\text { sounds in the } \\
\text { classroom, even when } \\
\text { we are silent }\end{array}$ & $\begin{array}{c}3,93 \\
(1,13)\end{array}$ & $\begin{array}{c}4,51 \\
(0,78)\end{array}$ & $\begin{array}{c}\mathrm{W}= \\
-3,724 \mathrm{p}<.05\end{array}$ \\
\hline
\end{tabular}

In view of these results, it is possible to conclude that the activities of the experiment had a positive influence on the acquisition of children's knowledge in what concerns the investigated questions. It is worth mentioning that the knowledge implicit and explicit in those questions was promoted with the use of electronic sensors together with the safeness sound scales, this way showing children's significant learning linked to the use of ICT.

The analysis of the differences between girls' and boys' answers to the posttest knowledge questions made it possible to verify that there are no statistically significant differences (Table IV). This way, it is possible to state that the implemented activities did not contribute to gender differences in the acquisition of knowledge. This is a positive aspect of the use of eco-sensors in STEM activities to explore and solve environmental health problems by children.

TABLE IV. NONPARAMETRIC MANN-WHITNEY TEST ANALYSIS OF GENDER DIFFERENCES IN PRE AND POSTTEST KNOWLEDGE QUESTIONS ABOUT SOUND

\begin{tabular}{|r|c|c|c|}
\hline \multirow{2}{*}{ Questions } & Girls & Boys & \multirow{2}{*}{$\begin{array}{c}\text { Mann- } \\
\text { Whitney test }\end{array}$} \\
\cline { 2 - 3 } & $\begin{array}{r}\text { Posttest average } \\
\text { and standard } \\
\text { deviation }\end{array}$ & \\
\hline $\begin{array}{r}\text { To improve the quality } \\
\text { of the environment, } \\
\text { noise should be avoided }\end{array}$ & $\begin{array}{c}4,21 \\
(0,97)\end{array}$ & $\begin{array}{c}4,41 \\
(0,82)\end{array}$ & $\begin{array}{c}\mathrm{U}=558,000 \\
\mathrm{p}>.05 \\
\text { (nonsignificant) }\end{array}$ \\
\hline $\begin{array}{r}\text { A high sound level is } \\
\text { harmful to health }\end{array}$ & $\begin{array}{c}4,02 \\
(1,12)\end{array}$ & $\begin{array}{c}4,14 \\
(1,41)\end{array}$ & $\begin{array}{c}\mathrm{U}=531,500 \\
\mathrm{p}>.05 \\
\text { (nonsignificant) }\end{array}$ \\
\hline $\begin{array}{r}\text { There are always sounds } \\
\text { in the classroom, even } \\
\text { when we are silent }\end{array}$ & $\begin{array}{c}4,49 \\
(0,83)\end{array}$ & $\begin{array}{c}4,45 \\
(0,69)\end{array}$ & $\begin{array}{c}\mathrm{U}=609,000 \\
\mathrm{p}>.05 \\
\text { (nonsignificant) }\end{array}$ \\
\hline
\end{tabular}

The only questions of the posttest that registered statistically significant differences between girls and boys are related to environmental and health awareness (Table V).
TABLE V. NONPARAMETRIC MANN-WHITNEY TEST ANALYSIS OF GENDER DIFFERENCES IN POSTTEST QUESTIONS ABOUT ENVIRONMENTAL AND HEALTH AWARENESS

\begin{tabular}{|c|c|c|c|}
\hline Questions & Girls & Boys & \multirow{2}{*}{$\begin{array}{c}\text { Mann- } \\
\text { Whitney } \\
\text { test }\end{array}$} \\
\cline { 2 - 3 } & \multicolumn{2}{|c|}{$\begin{array}{c}\text { Posttest average } \\
\text { and standard } \\
\text { deviation }\end{array}$} & $\begin{array}{c}\mathrm{U}=415,500 \\
\mathrm{p}<.05 \\
(\text { significant })\end{array}$ \\
\hline I pay close attention to \\
health news & $\begin{array}{c}4,00 \\
(0,85)\end{array}$ & $\begin{array}{c}3,31 \\
(1,26)\end{array}$ & $\begin{array}{c}\mathrm{U}=317,500 \\
\mathrm{p}<.05 \\
\text { (significant) }\end{array}$ \\
\hline $\begin{array}{r}\text { I pay close attention to the } \\
\text { news about the environment }\end{array}$ & $\begin{array}{c}4,21 \\
(0,89)\end{array}$ & $\begin{array}{c}3,14 \\
(1,30)\end{array}$ & \\
\hline
\end{tabular}

The girls improved their environmental and health awareness after participating in the experiment activities with eco-sensors (pretest average 3,93 and posttest average 4,00) and the boys decreased (pretest average 3,52 and posttest average 3,31). Although the differences between pre and posttest for the girls and the boys are small, the differences between girls' and boys' answers are statistically significant (Table V).

This result is in line with the results of previous studies, revisited in Martins, \& Veiga [21]. In those studies women expressed greater environmental concern than men, including in Portugal, where the use the Youth Attitudes towards the Environment scale allowed to identify significant differences between girls and boys, with more favorable results in girls [21] [22]. An education that favors affection and dependence on the exterior is a possible explanation for girls' suffering concern, and greater environmental [and health] concern and awareness [21] [22].

\section{B. Suggestions to solve the school sound problems}

In order to analyze if there are gender differences in the suggestions to solve the school sound problems, a content analysis was performed to the answers of the children. The frequencies of the different categories of boys' and girls' suggestions were compared (Table VI). Some children identified in a single answer, multiple suggestions, from different categories.

TABLE VI. FREQUENCIES OF THE DIFFERENT SUB/CATEGORIES OF SUGGESTIONS OF GIRLS AND BOYS TO SOLVE THE SCHOOL SOUND PROBLEMS

\begin{tabular}{|c|c|c|c|c|}
\hline \multirow{2}{*}{\multicolumn{2}{|c|}{ All schools }} & Girls & Boys & Total \\
\hline & & $n=43$ & $n=29$ & $n=72$ \\
\hline \multirow{4}{*}{$\begin{array}{r}\text { Do not produce } \\
\text { noise }\end{array}$} & $\begin{array}{l}\text { Talk low / do not shout / } \\
\text { to be silent }\end{array}$ & $58 \%$ & $55 \%$ & $57 \%$ \\
\hline & Do not drag furniture & $0 \%$ & $7 \%$ & $3 \%$ \\
\hline & Do not run & $7 \%$ & $0 \%$ & $4 \%$ \\
\hline & Other responses & $0 \%$ & $7 \%$ & $3 \%$ \\
\hline $\begin{array}{r}\text { Get others to not } \\
\text { produce noise }\end{array}$ & $\begin{array}{l}\text { Talk low / do not shout / } \\
\text { to be silent }\end{array}$ & $9 \%$ & $14 \%$ & $11 \%$ \\
\hline \multirow{3}{*}{$\begin{array}{r}\text { Place absorbent } \\
\text { material }\end{array}$} & $\begin{array}{l}\text { Change the interior } \\
\text { lining }\end{array}$ & $2 \%$ & $7 \%$ & $4 \%$ \\
\hline & Put liner inside & $21 \%$ & $14 \%$ & $18 \%$ \\
\hline & $\begin{array}{l}\text { Placing furniture and } \\
\text { objects }\end{array}$ & $14 \%$ & $10 \%$ & $13 \%$ \\
\hline $\begin{array}{l}\text { Do not be in } \\
\text { noisy places }\end{array}$ & & $2 \%$ & $3 \%$ & $3 \%$ \\
\hline I don't know & & $0 \%$ & $3 \%$ & $1 \%$ \\
\hline
\end{tabular}


The results of the content analysis don't evidence substantial differences between boys' and girls' answers. The registered frequencies of the primary categories are globally balanced in what concerns gender. Nevertheless, it is noteworthy that a bigger percentage of girls, compared to percentage of boys, suggested to "Place absorbent material", namely by putting liner inside, and by placing furniture and objects, to solve school sound problems. In contrast, a bigger percentage of boys, compared to percentage of girls, suggested to "Get others to not produce noise".

Interestingly, only girls suggested "Do not run", and only boys suggested "Do not drag furniture" to not "produce noise".

Some examples of girls' and boys' suggestions to solve the school sound problems:

"We can lower the sound levels in our school by putting more cork-like things and other things to lessen the sound" (Girl, age 10).

"We can reduce sound levels in our school by putting objects that absorb sound, for example: putting a carpet, cork, ceilings ..." (Girl, age 9).

"Tell the boys to speak lower in the playground and in the classroom" (Boy, 9 years old). old).

"Telling others not to disturb our hearing" (Boy, 10 years

"Do not drag chairs and do not scream" (Boy, 9 years).

"Not running in the spaces (corridors, classrooms, canteen, etc.) because it causes sound" (Girl, 9 years).

\section{CONCLUSION}

Facing the need for closing STEM and digital competences gender gaps [1], in this research, an environmental health experiment, developed with primary school children of four classes (one of each participant school), was assessed with a gender perspective. This experiment was designed to be gender neutral, i.e. designed for all children, boys and girls, including elements that can potentially make STEM curricula more attractive to girls, such as: female teachers; hands-on activities; project-based learning; scientific inquiry, with real-world experience; reflection and conceptualization, as well as time and experience with technology [3].

In the developed experiment, children made use of electronic sensors (sound sensors), together with tablets, to explore and solve school environmental health problems, specifically sound pollution problems. The results of the pre and posttests showed that children acquired environmental health knowledge related to sound pollution in school, with differences between answers to pre and posttest being statistically significant. Furthermore, the results of the posttests also showed that there were no statistically significant differences between boys' and girls' answers to the knowledge questions. Nevertheless, in accordance with related studies [21] [22], there were statistically significant differences between girls and boys in what concerns environmental and health awareness questions.

Additionally, the results of a content analysis to the children's suggestions to solve the school sound problem showed that children were able to propose relevant solutions to solve the studied problems but showed no global gender differences.

Accordingly, it is possible to state that the experiment that challenged primary school children to explore and solve school sound pollution problems, using electronic sensors, was assessed as producing no significant gender differences. These kinds of activities can contribute to close STEM and ICT gender gaps, specifically in what concerns younger children, fostering their motivation and self-efficacy to prevent deepening those gaps in later school stages [4] [3].

\section{ACKNOWLEDGMENT}

The development of the experiment assessed in this research was part of the Eco-Sensors4Health Project The EcoSensors4Health project (LISBOA-01-0145-FEDER-023235) is supported by FEDER (PORTUGAL2020) and Portugal State Budget.

The assessment of that experiment, with a gender perspective, was part of the "Digital literacy in the context of scientific education: Gender Issues" project. This is a project of the Interdisciplinary Center for Educational Studies (CIED), School of Education, Polytechnic Institute of Lisbon.

\section{REFERENCES}

[1] OECD, "The $\mathrm{ABC}$ of gender equality in education: Aptitude, behaviour, confidence," Paris: OECD, 2015. [Online]. Available: http://www.oecd.org/pisa/keyfindings/pisa-2012-results-gendereng.pdf

[2] J. Maric, "The gender-based digital divide in maker culture: features, challenges and possible solutions," Journal of Innovation Economics \& Management, vol. 27, no. 3, pp. 147-168, 2018, doi:10.3917/jie.027.0147.

[3] UNESCO, "Cracking the Code: Girls' and Women's Education in Science, Technology, Engineering and Mathematics," Paris, France, 2017.

[4] M. West, R. Kraut and H. E. Chew, "I'd Blush If I Could: Closing Gender Divides in Digital Skills Through Education," UNESCO Report, Equals, May 2019.

[5] E. Kedzierska, "Primary Science with €Sense: Teacher Guide". Amsterdam: CMA, 2017. [Online]. Available: https://cmascience.nl/activities/en/primaryscience/teacher_support/Primary\%20S cience $\% 20$ Teacher\%20Guide.pdf

[6] E. van den Berg, F. Schweickert and R. van den Berg, "Science, Sensors and Graphs in Primary schools," in Proceedings of the GIREP Conference 2010, 2010.

[7] M. Fenton, Authentic learning using mobile sensor technology with reflections on the state of science education in New Zealand: A research project for the New Zealand Ministry of Education. Taranaki, New Zealand: Nexus Research Group, 2008.

[8] D. Holloway, L. Green and S. Livingstone, Zero to eight. Young children and their internet use. LSE, London: EU Kids Online, 2013.

[9] C. Ponte, J. A. Simões, S. Batista, A. Jorge and T. S. Castro, Crescendo entre ecrãs. Usos de meios eletrónicos por crianças (3-8 anos). Lisboa: ERC, 2017.

[10] M. Oliveira, "Perceções sobre a influência do género na aprendizagem das ciências e no prosseguimento de carreiras científicas: um estudo de métodos mistos," Ph.D. dissertation. Lisboa: Universidade de Lisboa, 2018.

[11] G. Stoet and D. C. Geary, "The Gender-Equality Paradox in Science, Technology, Engineering, and Mathematics Education," Psychological Science, vol 29, Issue 4, pp. 581-593, 2018.

[12] World Economic Forum, "New vision for education: Fostering social and emotional learning through technology," 2016. [Online]. 
Available:http://www3.weforum.org/docs/WEF_New_Vision_for_Ed ucation.pdf

[13] I.V.S. Mullis, M.O. Martin and T. Loveless, 20 Years of TIMSS: International Trends in Mathematics and Science Achievement Curriculum, and Instruction. Chestnut Hill, MA: Boston College, 2016.

[14] J. Marôco, V. Lourenço, R. Mendes and C. Gonçalves, TIMSS 2015 Portugal. Volume I: Desempenhos em Matemática e Ciências. Lisboa: IAVE,I.P, 2016.

[15] L. Holman, D. Stuart-Fox and C. E. Hauser, "The gender gap in science: How long until women are equally represented?," PLoS Biology, vol. 16, no. 4, 2018, https://doi.org/10.1371/journal.pbio.2004956.

[16] J. Osborne and J. Dillon, Science education in Europe: Critical reflections. London: The Nuffield Foundation, 2008.

[17] M. Lie, He, She and It Revisited: New Perspectives on Gender in the Information Society. Oslo: Gyldendal Akademisk, 2003.
[18] S. R. Stapleton, "Supporting teachers for race-, class-, and genderresponsive science teaching," Curriculum Studies of Science Education, vol. 10, pp. 411-418, 2015.

[19] E. Ferreira, "The co-production of gender and ICT: Gender stereotypes in schools," First Monday, vol. 22, no. 10, 2017, https://doi.org/10.5210/fm.v22i10.7062.

[20] J. Cassell, "Genderizing HCI," in The Handbook of Human-Computer Interaction, J. Jacko and A. Sears, Eds., Mahwah, NJ: Lawrence and Erlbaum, 2002, pp.402-411.

[21] C. Martins and F. Veiga, "Atitudes dos jovens alunos face ao ambiente, idade e sexo: Uma revisão da literatura," in Envolvimento dos alunos na escola: Perspetivas da psicologia e educação - Motivação para o desempenho académico, F. Veiga, Ed., Lisboa: Universidade de Lisboa, Instituto de Educação, 2016, pp. 634-654.

[22] M. C. Martins, "Atitudes dos jovens face ao ambiente: Perspetiva diferencial e desenvolvimentista," MSc. Dissertation. Lisboa: Departamento de Educação da Faculdade de Ciências da Universidade de Lisboa, 1996. 